\title{
Biogeochemical processes controlling oxygen and carbon isotopes of diatom silica in Late Glacial to Holocene lacustrine rhythmites
}

\author{
Armand Hernández ${ }^{\mathrm{a}, \mathrm{b}, *}$, Roberto Bao ${ }^{\mathrm{c}}$, Santiago Giralt ${ }^{\mathrm{a}}$, Philip A. Barker ${ }^{\mathrm{d}}$, Melanie J. Leng ${ }^{\mathrm{e}}$, \\ Hilary J. Sloane ${ }^{\mathrm{e}}$, Alberto Sáez ${ }^{\mathrm{b}}$ \\ a Institute of Earth Sciences Jaume Almera-CSIC, C/Lluís Solé i Sabarís s/n, 08028 Barcelona, Spain \\ ${ }^{b}$ Faculty of Geology, University of Barcelona, C/ Martí Franquès s/n, 08028 Barcelona, Spain \\ ${ }^{c}$ Faculty of Sciences, University of A Coruña, Campus da Zapateira s/n, 15071 A Coruña, Spain \\ d Lancaster Environment Centre, Lancaster University, Lancaster LA1 4YQ UK \\ e NERC Isotope Geosciences Laboratory, British Geological Survey, Nottingham NG12 5GG, UK
}

\section{A R T I C L E I N F O}

\section{Article history:}

Received 19 May 2010

Received in revised form 19 November 2010

Accepted 22 November 2010

Available online 29 November 2010

\section{Keywords:}

Oxygen isotopes

Carbon isotopes

Diatoms

Lacustrine sediments

Andean Altiplano

ENSO

\begin{abstract}
A B S T R A C T
Biogeochemical cycles and sedimentary records in lakes are related to climate controls on hydrology and catchment processes. Changes in the isotopic composition of the diatom frustules $\left(\delta^{18} \mathrm{O}_{\text {diatom }}\right.$ and $\left.\delta^{13} \mathrm{C}_{\text {diatom }}\right)$ in lacustrine sediments can be used to reconstruct palaeoclimatic and palaeoenvironmental changes. The Lago Chungará (Andean Altiplano, 18 ${ }^{\circ} 15^{\prime} \mathrm{S}, 69^{\circ} 10^{\prime} \mathrm{W}, 4520$ masl) diatomaceous laminated sediments are made up of white and green multiannual rhythmites. White laminae were formed during short-term diatom superblooms, and are composed almost exclusively of large-sized Cyclostephanos andinus. These diatoms bloom during mixing events when recycled nutrients from the bottom waters are brought to the surface and/or when nutrients are introduced from the catchment during periods of strong runoff. Conversely, the green laminae are thought to have been deposited over several years and are composed of a mixture of diatoms (mainly smaller valves of $C$. andinus and Discostella stelligera) and organic matter. These green laminae reflect the lake's hydrological recovery from a status favouring the diatom super-blooms (white laminae) towards baseline conditions. $\delta^{18} \mathrm{O}_{\text {diatom }}$ and $\delta^{13} \mathrm{C}_{\text {diatom }}$ from 11,990 to 11,530 cal years BP allow us to reconstruct shifts in the precipitation/evaporation ratio and changes in the lake water dissolved carbon concentration, respectively. $\delta^{18} \mathrm{O}_{\text {diatom }}$ values indicate that white laminae formation occurred mainly during low lake level stages, whereas green laminae formation generally occurred during high lake level stages. The isotope and chronostratigraphical data together suggest that white laminae deposition is caused by extraordinary environmental events. El Niño-Southern Oscillation and changes in solar activity are the most likely climate forcing mechanisms that could trigger such events, favouring hydrological changes at interannual-to-decadal scale. This study demonstrates the potential for laminated lake sediments to document extreme pluriannual events.
\end{abstract}

(c) 2010 Elsevier B.V. All rights reserved.

\section{Introduction}

Rhythmites are finely laminated sequences (millimetre- to submillimetre thick) made up of regular alternations of two or three contrasting sediment types called couplets or triplets (Talbot and Allen, 1996). Rhythmite formation is generally associated with seasonally heterogeneous sediment supply and a lack of physical or biological reworking processes (Grimm et al., 1996). Thus, laminated sediments indicate high-frequency environmental change through time. A number of studies have described laminated lacustrine sediments, but they have mainly dealt with annual-rhythmites (varves) with different clastic grain-sizes and/or biogenic contents

\footnotetext{
* Corresponding author. Institute of Earth Sciences Jaume Almera-CSIC, C/Lluis Solé i Sabarís s/n, E-08028 Barcelona, Spain. Tel.: +34 934095 410; fax: +34 934110012. E-mail address: ahernandez@ija.csic.es (A. Hernández).
}

deposited over different seasons (e.g. Bird et al., 2009). The processes that lead to rhythmite formation at mid- to high latitudes are often well constrained (e.g. Chang et al., 2003), whereas the biogeochemical processes and climate events which prompt laminated sediments in tropical lacustrine sediments are often less understood. In these cases, tropical rainfall regimes associated with intense storms and wind may be responsible for extraordinary external nutrient loading or upwelling of nutrient rich-waters which trigger phytoplankton blooms (Talbot and Allen, 1996). These tropical climate regimes follow a seasonal behaviour (e.g. monsoons), but they can also be highly influenced by climatic multiannual phenomena (e.g. ENSO).

Changes in the oxygen isotopic composition of the diatom frustules $\left(\delta^{18} \mathrm{O}_{\text {diatom }}\right)$ in lacustrine sediments are used to infer hydrological variations. For closed lakes in the tropics, these variations are mostly related to the precipitation/evaporation ratio $(\mathrm{P} / \mathrm{E})$, which is, in general, directly linked to lake level change (Leng and Barker, 
2006). The isotope-inferred reconstructions can thus be used to reveal the climate history of the region (e.g. Barker et al., 2007) although this may be mitigated by biological and sedimentary processes. Besides $\delta^{18} \mathrm{O}_{\text {diatom }}$, the isotopic signature of carbon occluded within the diatom silica $\left(\delta^{13} \mathrm{C}_{\text {diatom }}\right)$, can give other relevant palaeoenvironmental information, including insights on the lakes' carbon cycle. There are few studies of carbon isotopes from organic inclusions within diatom frustules, and of those published, most have dealt with marine sedimentary records (e.g. Crosta and Shemesh, 2002). Studies on $\delta^{13} \mathrm{C}_{\text {diatom }}$ in lake sediments are now emerging and providing valuable insights into the complex carbon cycle of lakes (Hurrell, 2010).

The aim of this paper is to understand high frequency biological, chemical and sedimentary processes which cause the laminae formation in the sedimentary record of Lago Chungará, a high altitude tropical lake located in the Central Andes. $\delta^{18} \mathrm{O}_{\text {diatom }}$ and $\delta^{13} \mathrm{C}_{\text {diatom }}$ data from individual laminae are presented for a period between 11,990 and $11,530 \mathrm{cal}$ years BP. High frequency environmental perturbations brought about by interannual-decadal climatic events are rarely recorded in lake sediments, and therefore, the laminated sediments are a good record of their intensity and their effect on lacustrine hydrological and carbon cycles.

\section{Lago Chungará setting}

\subsection{Geology, limnology and climate}

Lago Chungará $\left(18^{\circ} 15^{\prime} \mathrm{S}, 69^{\circ} 10^{\prime} \mathrm{W}, 4520\right.$ masl $)$ is a cold-polymictic and oligo- to meso-eutrophic lake located in the Andean Altiplano (Fig. 1A). The lake sits on the Cenozoic Lauca Basin surrounded by volcanoes. The Chungará infill mostly comprises organic diatomaceous sediments with abundant tephra from the Parinacota Volcano, which was active during most of the Late Glacial and Holocene (Sáez et al., 2007). The lake occupies $21.5 \mathrm{~km}^{2}$ and has a maximum water depth of $40 \mathrm{~m}$ (Fig. 1B). It is moderately alkaline ( $\mathrm{pH}$ between 8.99 and 9.30), well mixed (7.6 $\mathrm{ppm} \mathrm{O}_{2}$ at $34 \mathrm{~m}$ deep), salinity is around $1.2 \mathrm{~g} \mathrm{l}^{-1}$, conductivity values range between 1500 and $3000 \mu \mathrm{Sm}^{-1}$ and waters are of the $\mathrm{Na}^{+}-\mathrm{Mg}^{2+}-\mathrm{HCO}_{3}^{-}-\mathrm{SO}_{4}^{2-}$ type (Sáez et al., 2007). The phytoplankton community is made up of a few major species; diatoms dominate the cold season, whereas Chlorophyceae are more abundant during the austral summer (Dorador et al., 2003). Macrophyte communities form dense patches and microbial colonies in the littoral zone contribute to primary productivity. The local vegetation in the catchment is characterised by low cover values $(<30 \%)$, being dominated by grasses, shrubs, soligenous peatlands, and Polylepis dwarf forests (Moreno et al., 2007).

The lake is considered hydrologically closed as there is no surface outlet and the residence time of the lake water is approximately 15 years (Herrera et al., 2006). The main inlet to the lake is the Chungará River (300-460 $1 \mathrm{~s}^{-1}$ ), whereas evaporation causes the main water loss $\left(3.10^{7} \mathrm{~m}^{3} \mathrm{yr}^{-1}\right)$ and represents about $80 \%$ of the total outflow. The $\delta^{18} \mathrm{O}$ and $\delta \mathrm{D}$ composition of the lake water in 2002 and 2004 (c. - 1.4\% and c. $-43.4 \%$, respectively) diverge significantly from the Global Meteoric Water Line (GMWL), the Regional Meteoric Water Line (RMWL, where $\delta^{18} \mathrm{O}$ c. $-14.3 \%$ and $\delta \mathrm{D}$ c. $-95 \%$ ) and isotope composition of the inflowing water $(-12.6 \%$ and $-108.5 \%$, respectively) (Herrera et al., 2006). The lake water is enriched compared to the inflowing water $\left(\delta^{18} \mathrm{O}\right.$ by $+11.2 \%$ and $\delta \mathrm{D}$ by $+65 \%$ ) due to evaporation.

The climate in the Lago Chungará region is dominated by semi-arid conditions due to the influence of the South Pacific Anticyclone (Fig. 1A). The modern mean annual temperature at Lago Chungará is $+4.2^{\circ} \mathrm{C}$, with higher thermal oscillations between day/night (mean difference $=22{ }^{\circ} \mathrm{C}$ ) than summer/winter (mean difference $=6{ }^{\circ} \mathrm{C}$ ). A variable precipitation pattern dominates this region, where the annual rainfall ranges from 100 to $750 \mathrm{~mm} \mathrm{yr}^{-1}$ (mean $411 \mathrm{~mm} \mathrm{yr}^{-1}$ ), and more than the $70 \%$ of it falls during the austral summer (DecemberFebruary). At this time, a strong low pressure region, known as the
South American Summer Monsoon (SASM), is formed over Central South America driving convection and pulling moisture from the equatorial Atlantic to the Andean Altiplano (Vuille and Werner, 2005) (Fig. 1A). The SASM is a major component of the climate system over tropical and subtropical South America during the austral summer and is remotely forced by tropical Pacific SSTs (Vuille and Werner, 2005). At interannual timescales, El Niño-Southern Oscillation (ENSO) is the most important forcing causing climatic fluctuations over the tropical Americas as it controls changes in the Pacific Tropical Sea Surface Temperatures (SSTs) (Vuille et al., 2003) and therefore the evolution of the SASM. Instrumental data from the Chungará region show a reduction of the precipitation during moderate to intense El Niño years. However, there is no direct relationship between the relative El Niño strength and the amount of rainfall reduction (for further details see Valero-Garcés et al., 2003). Moreover, decadal variations in solar activity are related to the atmospheric circulation (Christoforou and Hameed, 1997) modulating the sign and strength of the westerly wind flow, which reduces the delivery of the moisture from the east above the Altiplano (Theissen et al., 2008). Previously published data dealing with the laminated sediments of Lago Chungará suggest that (at least during the Late Glacial-Early Holocene transition) there is an interaction between the solar activity and ENSO (Hernández et al., 2010). The solar activity forcing was likely transmitted to the Andean Altiplano via ENSO modulation of the SASM.

However, ENSO activity was not regular during the Late Glacial and the Holocene. The onset of the Holocene is characterised by a weakening and reduction of amplitude of the ENSO (Moy et al., 2002; Rodbell et al., 1999). The establishment of a long-term La Niña pattern in the tropical Pacific during this period seems to be a consequence of the ENSO activity reduction (Hernández et al., 2010; Koutavas et al., 2002). Onset of the present day ENSO conditions occurred at about 7000 cal years BP (Moy et al., 2002; Sandweiss et al., 2001).

\subsection{Sedimentary model}

Stratigraphy and facies association for the uppermost part of the Lago Chungará sequence was established by fifteen Kullenberg cores and seismic imagery (Sáez et al., 2007). Laminated sediments present in the lowermost recovered unit 1 defined in Sáez et al. (2007) were divided in the subunits $1 \mathrm{a}$ and $1 \mathrm{~b}$ according to its green or brown dominating colour and were correlated over the lake offshore zone (Fig. 1C).

The chronological model for the sedimentary sequence of Lago Chungará is based on 17 AMS ${ }^{14} \mathrm{C}$ dates of bulk organic matter and aquatic plant macrofossils, and one ${ }^{238} \mathrm{U} /{ }^{230} \mathrm{Th}$ date from carbonates (Giralt et al., 2008; Moreno et al., 2007). The main problems encountered in the construction of reliable chronological frameworks for the lacustrine sedimentary infill of most lakes in the Andean Altiplano are the determination of the radiocarbon reservoir effect and its change through time (Geyh and Grosjean, 2000). A reservoir effect of 3260 years was determined based on AMS ${ }^{14} \mathrm{C}$ dating of modern DIC and subsequent correction for atmospheric thermonuclear bomb tests of the late 1950s-early 1960s (Giralt et al., 2008). However, due to changes in the volume/surface ratio of the lake that took place during the deposition of the unit 1 (Hernández et al., 2008), the reservoir effect could have changed between values of 0 to 3260 years (Geyh et al., 1998). A mid point value was calculated between the two extreme reservoir ages and this value was used for constructing the age-depth model (further details in Giralt et al., 2008 and references therein).The calibration of radiocarbon dates was performed using CALIB 5.02 software and the INTCAL98 curve.

A petrographical study established a preliminary depositional rhythmite type for those sediments where rhythmites are composed of variable-thickness couplets of light-white and dark-green laminae (Hernández et al., 2008). According to the chronological model, each couplet was deposited during time intervals ranging from 4 to 24 years (Hernández et al., 2008). 

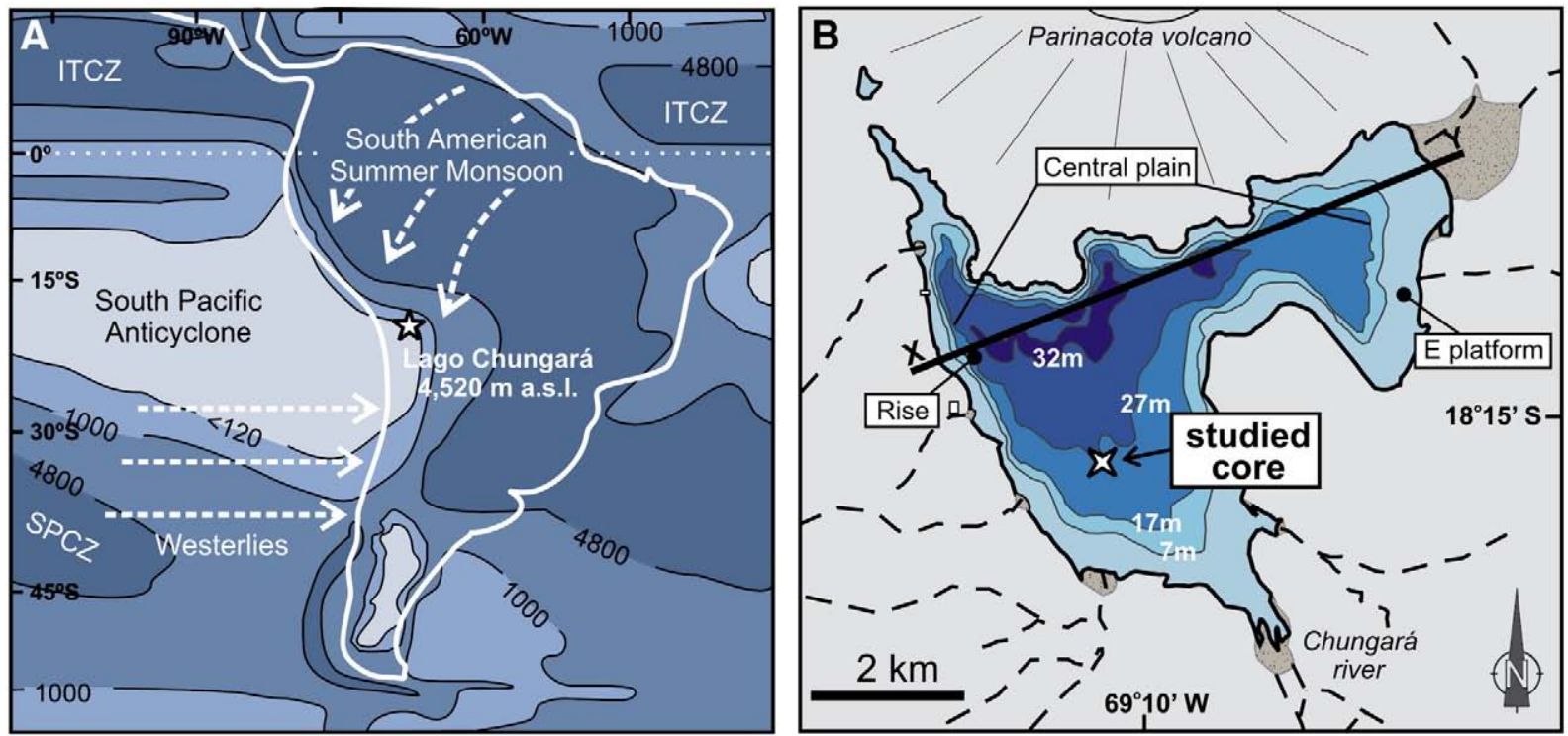

\section{$C_{x}$}

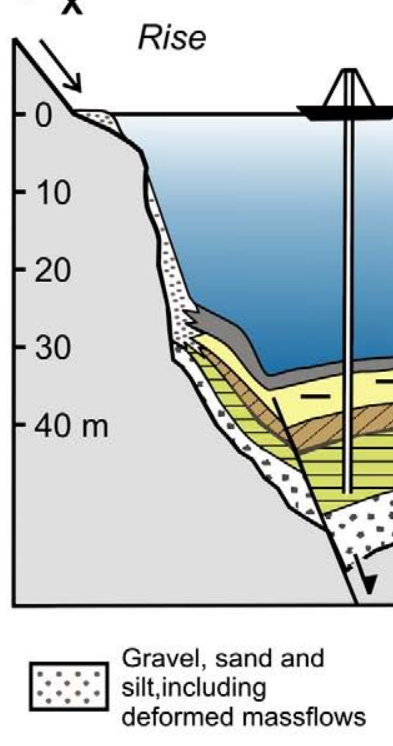

Peat, silt and

diatomaceous oozes

rich in charophytes

and molluscs

Central plain

E platform

$\mathbf{Y}$ 
method involved chemical attack, sieving, settling and laminar flow separation. The chemical attack followed standard procedures to remove the carbonates $(10 \% \mathrm{HCl})$ and organic matter $\left(\mathrm{H}_{2} \mathrm{O}_{2}\right)$, but also included a further step using concentrated $\mathrm{HNO}_{3}$ to eliminate any remaining organic matter. Sieving was undertaken at 125, 63 and $38 \mu \mathrm{m}$ and eliminated resistant charcoal and terrigenous particles. The settling was performed to separate the remaining particles with different densities. Finally, gravitational split-flow thin fractionation (SPLITT) was applied to the most problematic samples which still contained clay or fine tephra particles. Once the samples were purified, they were dried at $40{ }^{\circ} \mathrm{C}$ between $24 \mathrm{~h}$ and $48 \mathrm{~h}$. Finally, the purity of the samples was checked using microscopy and SEM to ensure that only isotope signals from the diatom silica components were obtained.

For $\delta^{18} \mathrm{O}_{\text {diatom }}$ analyses the classical step-wise fluorination method was applied to strip hydrous components from diatom silica before a full reaction with $\mathrm{BrF}_{5}$ (Leng and Barker, 2006; Leng and Sloane, 2008). The oxygen liberated was then converted to $\mathrm{CO}_{2}$ and normalised through the laboratory standard (BFC) and the NBS-28 quartz standard, referenced to VSMOW. A random selection of more than 30 samples was analysed in duplicate or even in triplicate giving a reproducibility between $0.0 \%$ and $0.3 \%$ o with a mean value of $0.15 \%$. Three samples with a reproducibility $>0.3 \%$ o were rejected. Isotope variations of consecutive samples are between $0 \%$ and $6.5 \%$, with a mean value of $1.0 \%$. Samples with differences $<0.15 \%$ o have not been used because they were considered essentially the same. As a consequence, 81 inter-sample relationships have been studied.

For $\delta^{13} C_{\text {diatom }}$ analysis of diatom-bound organic matter, we used combustion in an elemental analyser (Costech ECS4010) interfaced with a VG dual inlet isotope ratio mass spectrometer. The $\delta^{13} \mathrm{C}_{\text {diatom }}$ values were calculated to the VPDB scale using within-run laboratory standards calibrated against NBS18 and 19, and additionally cross checked with NBS22. \% $C_{\text {diatom }}$ analyses were performed by combustion separately in the elemental analyser calibrated against an
Acetanilide standard. Replicate $\delta^{13} \mathrm{C}_{\text {diatom }}$ and \%C analysis of wellmixed samples indicate a precision of $\pm<0.1 \%$. All the isotope analyses were carried out at the NERC Isotope Geosciences Laboratory, British Geological Survey (UK).

\section{Results}

\subsection{Laminae biogenic composition}

A hundred laminae, from the Late Glacial to Early Holocene transition (11,990-11,530 cal years BP), have been differentiated and grouped under white, light-green and dark-green laminae categories according to their diatom composition, organic matter content and colour. Nine laminae were undifferentiated because they had mixed features belonging to the three categories (Fig. 3).

White laminae are formed almost exclusively by diatom frustules of the large (diameter $>50 \mu \mathrm{m}$ ) euplanktonic diatom Cyclostephanos andinus (Fig. 4G). Dark-green laminae, which have a higher organic matter content probably derived from diatoms and other algal groups, are made up of a mixture of different diatom species. This mixture is mainly composed of smaller (diameter $<50 \mu \mathrm{m}$ ) C. andinus valves, with Discostella stelligera as co-dominant species. Subdominant diatom taxa comprise a number of tychoplanktonic (mainly Staurosira construens aff. venter and Fragilaria spp.) and benthic life forms (including Cocconeis placentula, Gomphonema minutum, Nitzschia tropica and Opephora sp. aff. mutabilis) (Fig. 4C). The light-green laminae are made up of components from the white laminae progressively grading upwards to the typical constituents of the dark-green laminae. Diatoms of the light-green laminae are usually embedded in an organic matrix creating a preferential orientation of the valves (Fig. 4B and E). Thus, a lower white lamina, an intermediate light-green lamina and an upper dark-green lamina form a typical sedimentary triplet. These light-green laminae may be variable in

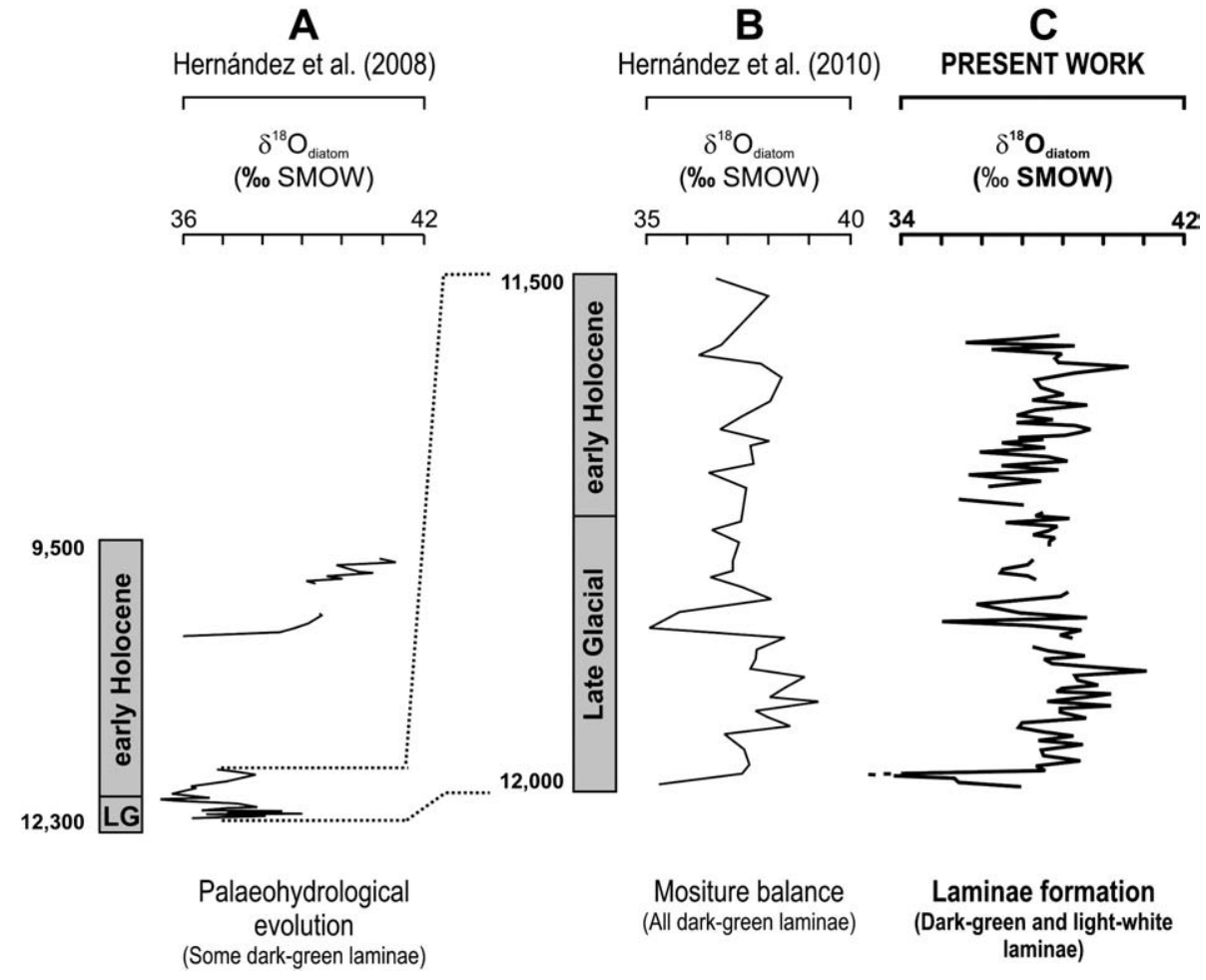

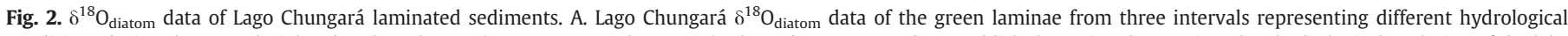

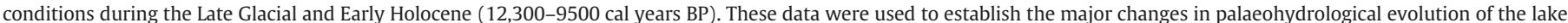

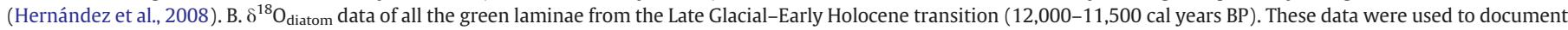

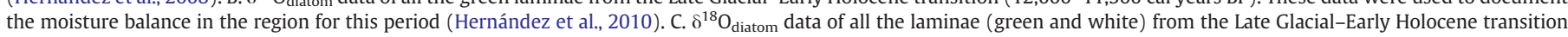
$(12,000-11,500$ cal years BP). These data are used in the present work to know the biogeochemical processes involved in the laminae formation. 


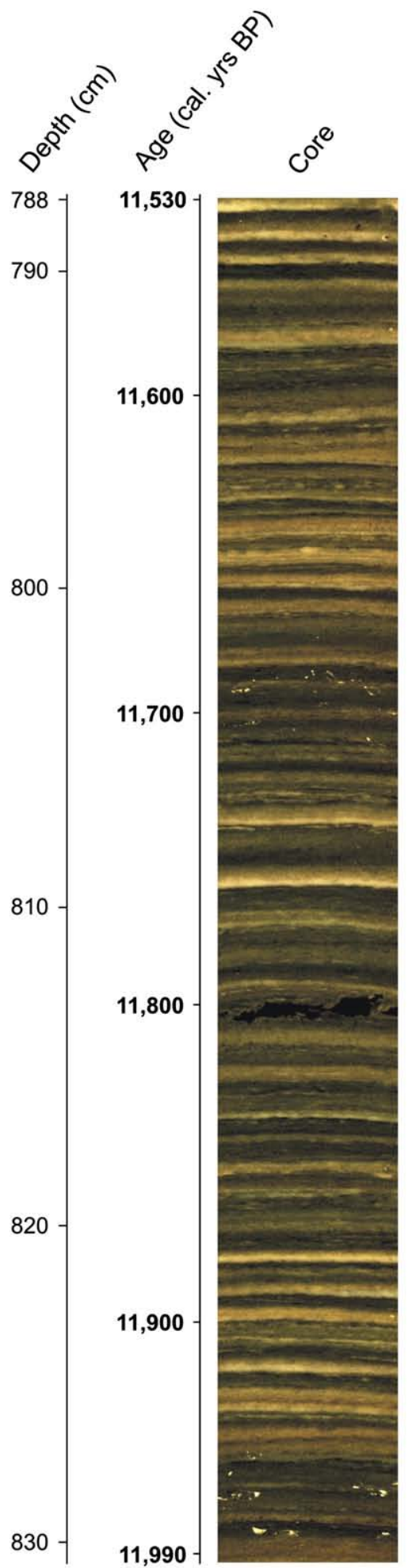

A

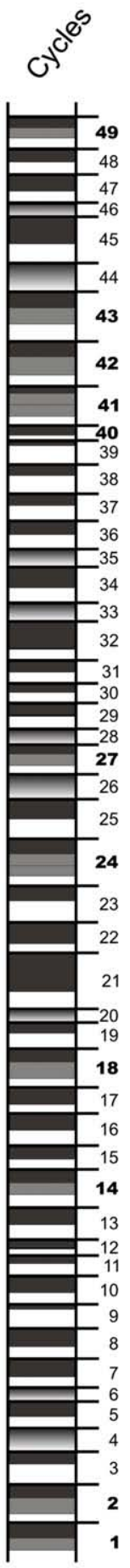

B

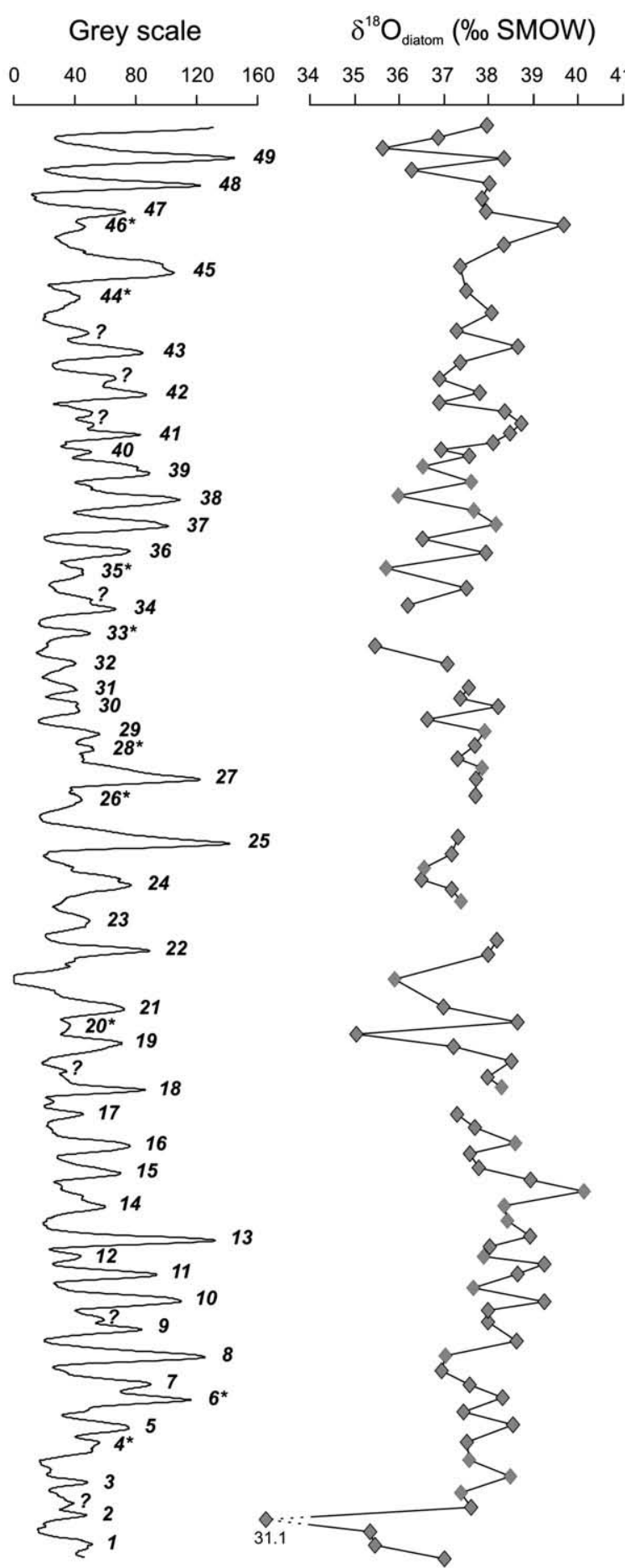

C

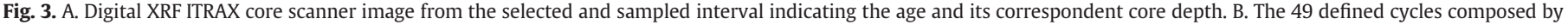

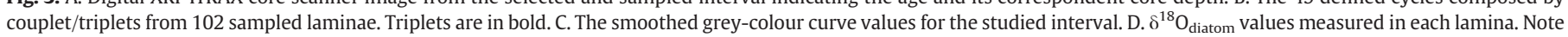
the diatom super-blooms are marked by thicker white laminae and higher values of the grey-colour curve.

thickness or even absent. The transition between well-defined laminae within the triplets (from here on called intra-cycle relationships) is gradual, whereas the transition between different triplets is abrupt (from here on called inter-cycle relationships) (Fig. 4 B, D, F and $\mathrm{H}$ ).

\subsection{Laminae isotope composition}

$\delta^{18} \mathrm{O}_{\text {diatom }}$ values display a large variability, ranging between $+40.1 \%$ and $+31.1 \%$ o with a mean value of $+37.5 \%$ o for the whole record $(S D=1.1, n=97$ ) (Fig. 3 ). The studied interval shows three 

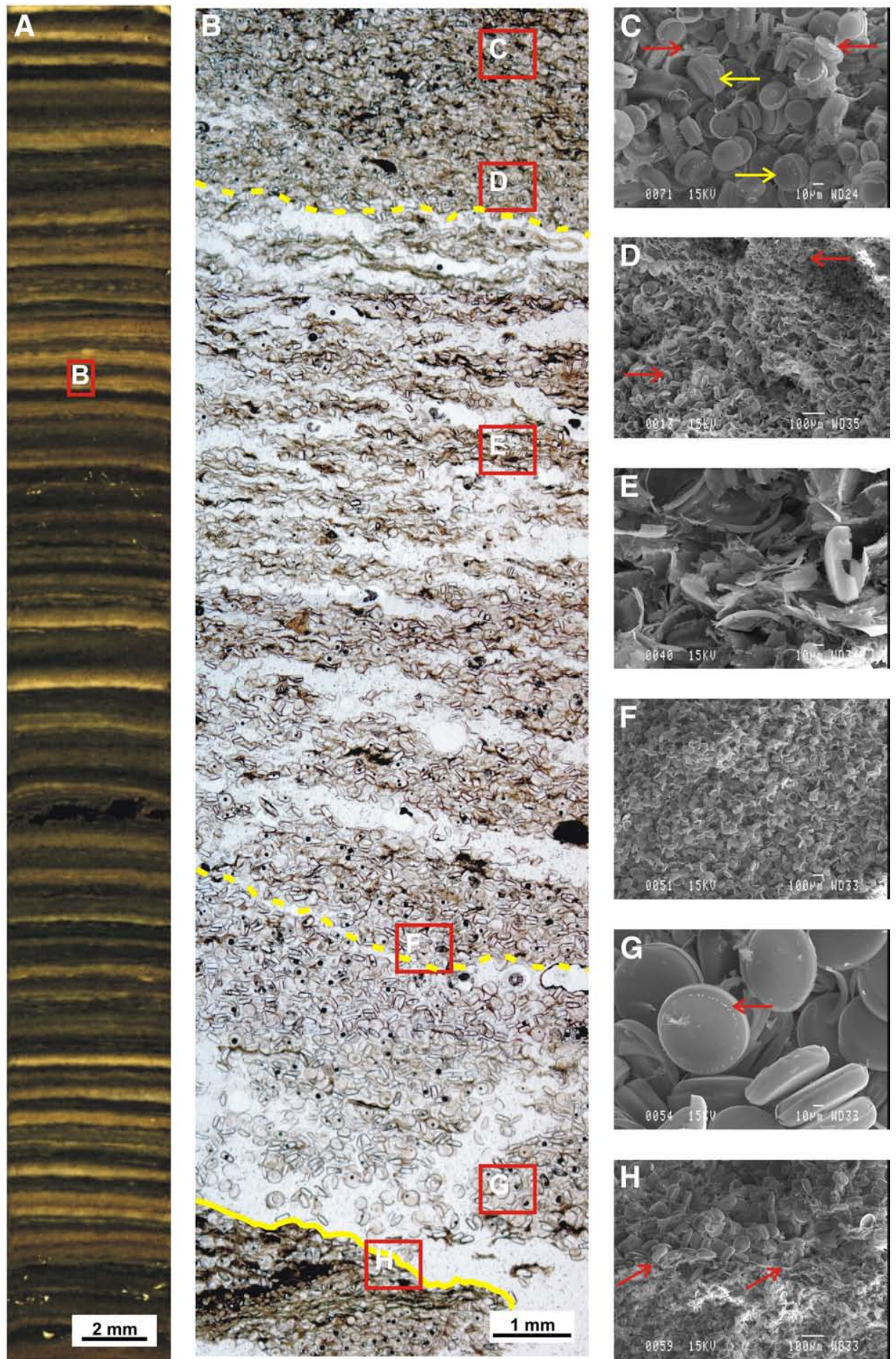

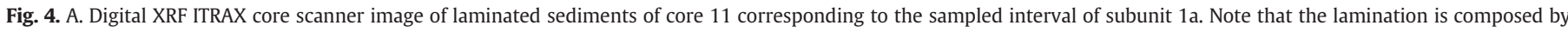

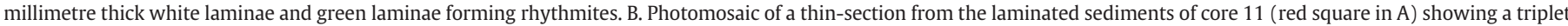

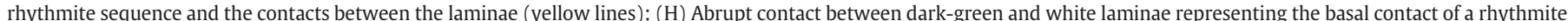

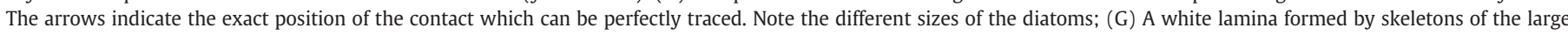

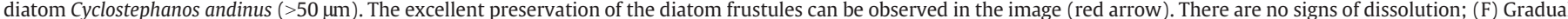

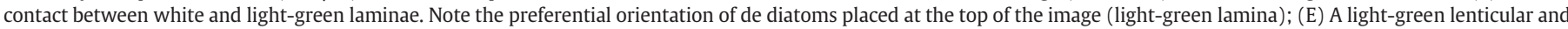

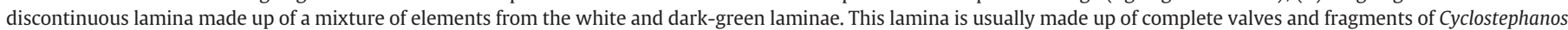

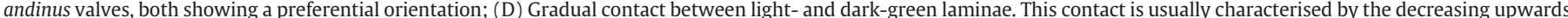

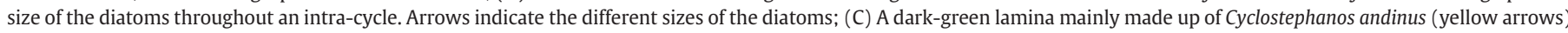
and Discostella stelligera (red arrows). Note the smaller Cyclostephanos andinus size (diameter $<50 \mu$ m) embedded in an organic matter matrix.

$\delta^{18} \mathrm{O}_{\text {diatom }}$ major enrichment trends which coincide with similar trends in the grey-colour curve (Fig. 5 ). The $\% \mathrm{C}_{\text {diatom }}$ values range from $0.63 \%$ in the uppermost sample (rhythmite 48 ) to $0.32 \%$ in the lowermost sample (rhythmite 8 ) (mean $=0.42 \%, \mathrm{SD}=0.10, \mathrm{n}=11$ ) whereas $\delta^{13} \mathrm{C}_{\text {diatom }}$ values oscillate between $-26.1 \%$ and $-29.5 \%$ o (mean $=-28.1 \%$, $\mathrm{SD}=0.95, \mathrm{n}=11$ ). The white laminae generally 


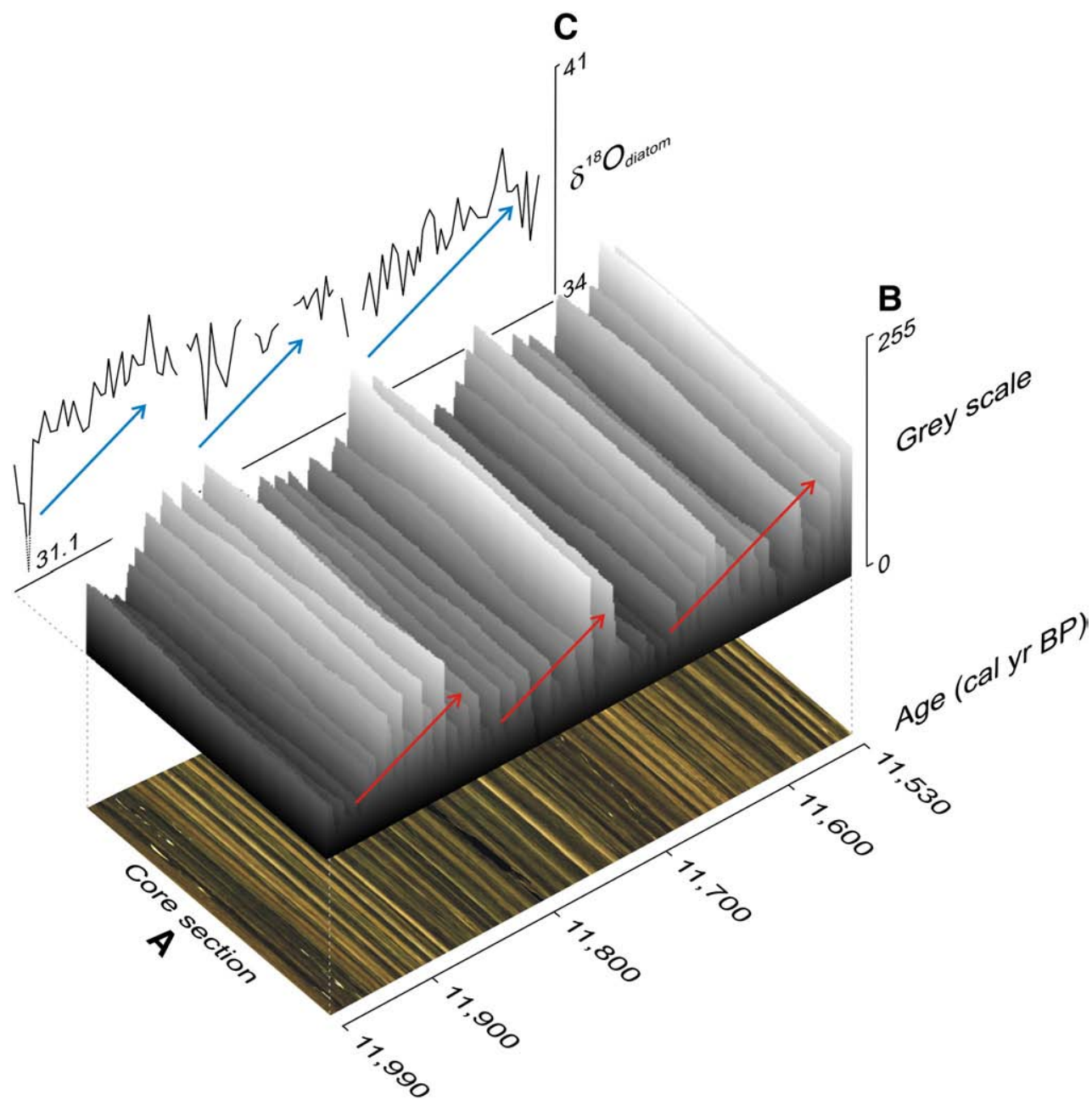

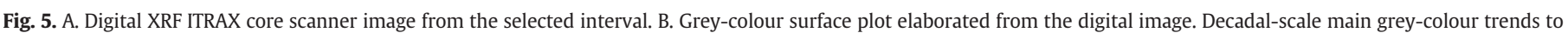

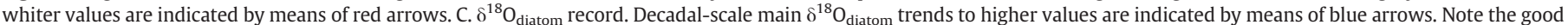
agreement between both proxies.

display lower $\% \mathrm{C}_{\text {diatom }}$ and $\delta{ }^{13} \mathrm{C}_{\text {diatom }}$ values than the dark laminae from the same rhythmite. In addition, there is an increase in the $\mathrm{C} / \mathrm{Si}$ ratios and $\delta^{13} C_{\text {diatom }}$ values throughout the 5 studied intra-cycle relationships (Table 1 ).

$\delta^{18} \mathrm{O}_{\text {diatom }}$ inter-cycle relationships have been studied in 49 cases. From these, 12 cases could not be taken into account due to the absence of $\delta^{18} \mathrm{O}_{\text {diatom }}$ data or because the difference between the two consecutive isotopic values was below the mean analytical error. Valid $\delta^{18} \mathrm{O}_{\text {diatom }}$ inter-cycle relationships $(\mathrm{n}=37)$ are characterised by higher oxygen isotope values. The most common inter-cycle rela- tionship is the dark-green to white laminae $(\mathrm{n}=25)$, and it shows isotope enrichment (i.e. values increase) in $60 \%$ of the cases. Likewise, the difference between dark-green laminae to undifferentiated laminae shows similar levels of increasing $\delta^{18} \mathrm{O}_{\text {diatom, whereas }}$ relationships between undifferentiated and white laminae show both increases and decreases in $\delta^{18} \mathrm{O}_{\text {diatom }}$ (Table 2A).

There are 51 valid (out of 62 ) relationships between laminae that take place within a rhythmite (intra-cycle relationships). These intracycle relationships are dominated by isotope depletions (values decrease). The most common case shows changes from white to dark-

Table 1

List of samples where both $\delta^{18} \mathrm{O}_{\text {diatom }}$ and $\delta^{13} \mathrm{C}_{\text {diatom }}$ analyses were carried out, including main sample features.

\begin{tabular}{|c|c|c|c|c|c|c|c|}
\hline Sample & Cycle & Colour & $\begin{array}{l}\text { Depth } \\
(\mathrm{cm})\end{array}$ & $\begin{array}{l}\text { Age } \\
\text { (cal yr BP) }\end{array}$ & $\begin{array}{l}\delta^{18} \mathrm{O}_{\text {diatom }} \\
(\mathrm{SMOW})\end{array}$ & $\begin{array}{l}\delta^{13} C_{\text {diatom }} \\
\text { (PDB) }\end{array}$ & $\% \mathrm{C}_{\text {diatom }}$ \\
\hline 5 & 48 & Dark-green & 789.1 & 11,543 & +36.27 & -28.99 & 0.63 \\
\hline 6 & 48 & White & 789.5 & 11,547 & +38.01 & -28.51 & 0.47 \\
\hline 13 & 43 & Dark-green & 793.4 & 11,588 & +38.07 & -26.05 & 0.57 \\
\hline 14 & 43 & Light-green & 794.1 & 11,595 & +37.29 & -28.30 & 0.38 \\
\hline 15 & 43 & White & 794.5 & 11,599 & +38.65 & -28.46 & 0.39 \\
\hline 29 & 37 & Dark-green & 799.3 & 11,650 & +37.67 & -27.87 & 0.40 \\
\hline 30 & 37 & White & 799.6 & 11,653 & +38.16 & -29.01 & 0.33 \\
\hline 77 & 13 & Dark-green & 820.5 & 11,872 & +38.44 & -27.21 & 0.44 \\
\hline 78 & 13 & White & 820.9 & 11,876 & +38.91 & -29.53 & 0.32 \\
\hline 87 & 8 & Dark-green & 824 & 11,909 & +38.62 & -27.69 & 0.38 \\
\hline 88 & 8 & White & 824.3 & 11,912 & +37.03 & -28.89 & 0.32 \\
\hline
\end{tabular}


Table 2

A. Inter-cycle isotope relationships between the defined rhythmites. B. Intra-cycle isotope relationships between the defined rhythmites. Relationship types are established according to the colour of the laminae that are in contact.

Enrichments Depletions $n$

(\%) (\%)

A. Inter-cycle relationship types
Dark-green to white laminae
Dark-green to undifferentiated laminae
Undifferentiated to white laminae
Total

$\begin{array}{rrr}60 & 40 & 25 \\ 67 & 33 & 6 \\ 50 & 50 & 6 \\ & & 37\end{array}$

B. Intra-cycle relationship types White laminae to light-green laminae Light-green to light-green laminae Light-green to dark-green laminae White laminae to dark-green laminae White laminae to dark-green laminae (non-consecutive laminae, base to top of the rhythmite) Total

$\begin{array}{rrr}33 & 67 & 9 \\ 0 & 100 & 1 \\ 56 & 44 & 9 \\ 35 & 65 & 23 \\ 33 & 67 & 9 \\ & & \\ & & 51\end{array}$

green laminae $(n=23)$, where isotope decreases occur in $67 \%$ of the cases (Table 2B).

\section{Discussion}

\subsection{Biological and sedimentary processes forming rhythmites}

The large thickness, the good diatom preservation and the monospecific diatom composition characterising white laminae suggest that they accumulated during short-term super-blooms, perhaps of only days to weeks in duration. According to the chronological model, rhythmites are not a product of annual variations in sediment supply, but due to some kind of multiannual processes (Hernández et al., 2008).

Any theory of the cause of these short-term super-blooms needs to take into account the injection of an extraordinary amount of nutrients into the euphotic zone, assuming enough light irradiance for photosynthesis is available. The two possible mechanisms for this input are enhanced vertical mixing of the water column that upwells nutrient-rich waters from the hypolimnion to the lake surface (Margalef, 1978; Winder and Hunter, 2008), and nutrient injection by increased runoff (Harris, 1986). Turbulence will be, in turn, dependent on both external forcing such as wind stress, surface heat flux, turbidity currents or river inflow and outflow, among others, and lake morphometry constraints (Imboden and Wüest, 1995). Accordingly we suggest two main scenarios for the formation of the superblooms in Lago Chungará: (1) low lake level and/or strong wind episodes that, facilitating turbulence, would select diatoms over other types of phytoplankton due to their relative buoyancy (Reynolds, 2006); and (2) extraordinary humid events that would increase runoff and therefore external nutrient loading (Bradbury et al., 2002). The ENSO cyclicity signal recorded at this time in the Lago Chungará sedimentary record (Hernández et al., 2010) provides support to the existence and prevalence of one of the two contrasting dry (El Niño) or humid (La Niña) conditions (Valero-Garcés et al., 2003).

Dark-green laminae represent the baseline lake conditions undisturbed by extreme events, where complete phytoplankton successions over several years are preserved. These laminae therefore record the 'normal' intra- and inter-annual changes in the water column mixing regime characterised by the shifting species composition throughout regular annual phytoplankton cycles. These relatively homogenous structures are marked by skeletons belonging to several diatom taxa, or simply as organic matter from other algal groups ( such as Chlorophyceae, Cyanobacteria, etc.). Normal seasonal diatom blooms, are manifested in the dark-green laminae by the abundance of the small Cyclostephanos andinus $(<50 \mu \mathrm{m})$, a large centric diatom whose buoyancy depends on the existence of a turbulent regime. Therefore, seasonal $C$. andinus $(<50 \mu \mathrm{m})$ blooms reflected in the dark-green laminae could be triggered by the same, but less intense, processes that prompted the super-blooms of the larger $C$. andinus ( $>50 \mu \mathrm{m})$ that make up the white laminae. The darkgreen laminae are sometimes preceded by light-green laminae indicating that recovery of the baseline conditions from the superblooms can be more or less gradual (forming couplets or triplets, respectively). The alternations of white and green laminae imply the absence of bioturbation (Grimm et al., 1996) and therefore would suggest anoxic conditions at the bottom of the lake, in contrast the lack of internal structures in the dark-green laminae suggest possibly suboxic conditions.

Flocculation of diatoms by extracellular polymeric substances is a common feature in the marine realm (Thornton, 2002). This phenomenon occurs towards the end of a diatom bloom, due to the onset of nutrient limitation. Diatom aggregation and subsequent rapid sedimentation of species having any kind of resting cell stages would favour future recruitment once nutrient resources were again available (Smetacek, 1985). Biosiliceous laminae in marine sediments have been interpreted as the product of changes in the mass sedimentation of diatoms by means of the formation of aggregates (Grimm et al., 1996, 1997). At Lago Chungará a similar phenomenon could have taken place in the formation of the lightgreen laminae once the super-blooms of the large $(>50 \mu \mathrm{m})$ Cyclostephanos andinus come to an end. Aggregation of cells enclosed in a gelatinous matrix could therefore have taken place, being rapidly deposited in the form of the transitional light-green laminae. Although the life cycle details of Cyclostephanos are far from fully known, the closely related genera Stephanodiscus, to which Cyclostephanos once belonged (Round et al., 1990), is known to produce resting cells (Sicko-Goad et al., 1989), whose aggregation and rapid sedimentation represents a transition to a resting phase (Alldredge et al., 1995; Smetacek, 1985). It is therefore likely that the mechanism of formation of triplets is mediated by processes of self-sedimentation triggered by $C$. andinus.

\section{2. $\delta^{18} \mathrm{O}_{\text {diatom }}, \delta^{13} C_{\text {diatom }}$ and $\% C_{\text {diatom }}$ interpretation}

Variation in $\delta^{18} \mathrm{O}_{\text {diatom }}$ can result from a variety of processes, such as oxygen isotope composition of the lake water $\left(\delta^{18} \mathrm{O}_{\text {lakewater }}\right)$, temperature, vital effects and post depositional diagenesis (Leng and Barker, 2006). In hydrologically closed lakes under arid climate conditions evaporative concentration processes have a much larger effect on $\delta^{18} \mathrm{O}_{\text {lakewater }}$ than any other process (Gasse and Fontes, 1992; Hernández et al., 2010; Leng and Marshall, 2004). In these circumstances, the $\delta^{18} \mathrm{O}_{\text {diatom }}$ record can be used as an indicator of changes in the $\mathrm{P} / \mathrm{E}$ related to climatic change (Leng and Barker, 2006).

At present, Lago Chungará can be considered a closed lake due to its water residence time (ca. 15 years), and the fact that $\delta^{18} \mathrm{O}_{\text {lakewater }}$ is enriched by $14 \%$ relative to $\delta^{18} \mathrm{O}$ of the isotope composition of the water inputs (precipitation, springs and river) (Herrera et al., 2006). We assume that this control has remained constant through time and that variations in the $\delta^{18} \mathrm{O}_{\text {diatom }}$ during Late Glacial-Early Holocene described here must be mainly derived from changes in the $\delta^{18} \mathrm{O}_{\text {lakewater }}$ resulting from shifts in the $\mathrm{P} / \mathrm{E}$ balance. This $\mathrm{P} / \mathrm{E}$ control on $\delta^{18} \mathrm{O}_{\text {diatom }}$ has also been implied from other tropical sites, such as lakes from Mount Kenya (Barker et al., 2001), Lake Malawi (Barker et al., 2007), and Lake Tilo in Ethiopia (Lamb et al., 2005).

The organic matter enclosed within diatom frustules contains polysaccharides, proteins and long-chain polyamines (Kröger and Poulsen, 2008). These substances host carbon which is protected from post-depositional diagenetic alteration (Des Combes et al., 2008). These carbon compounds are synthesised from the surrounding waters. Therefore, isotope analysis of the carbon of these compounds can be used as a proxy for reconstructing the lake's carbon cycle. 
Previously published studies suggest primary productivity and $\mathrm{CO}_{2(\mathrm{aq})}$ concentration as the main factors which determine $\delta^{13} \mathrm{C}_{\text {diatom }}$ in marine environments (Schneider-Mor et al., 2005). Nevertheless, lake $\delta^{13} \mathrm{C}_{\text {diatom }}$ is likely to be controlled by more complex environmental conditions making its interpretation less straightforward (Hurrell, 2010). $\delta^{13} C_{\text {diatom }}$ variations due to the species effect, cell size, growth rate or/and metabolic pathway are neglected in the present study because all $\delta^{13} C_{\text {diatom }}$ analyses were always carried out on similar sized-cells (38-62 $\mu \mathrm{m})$ and on the same diatom species (Cyclostephanos andinus).

The carbon isotope values from bulk sediment $\left(\delta^{13} C_{\text {bulk }}\right)$ in the Lago Chungará laminated unit range from $-21 \%$ o to $-19 \%$ o (Pueyo et al., submitted), yielding a difference of more than $5 \%$ o when compared to the measured $\delta{ }^{13} \mathrm{C}_{\text {diatom }}$ values. Yet, the $\mathrm{C} / \mathrm{N}$ ratios from bulk sediments of the laminated unit have values ranging between 7 and 11 (Pueyo et al., submitted), indicating that the $\delta^{13} C_{\text {bulk }}$ signal would have a mainly algal origin (Meyers and Teranes, 2001). For this reason, it seems that the $\delta^{13} C_{\text {diatom, }}$ rather than being mainly affected by changes in the source of organic matter, is mostly conditioned by changes in dissolved carbon concentration.

In lakes, it is commonly assumed that the carbon pool in the water becomes enriched in ${ }^{13} \mathrm{C}$ during the periods of enhanced productivity (Leng et al., 2005; Singer and Shemesh, 1995) since phytoplankton preferentially use the lighter isotope. Within-lake processes, such as changes in the mixing regime or organic matter decomposition, can however modify this pattern (Herzschuh et al., 2010; Mybro and Shapley, 2006). Preferential uptake of ${ }^{12} \mathrm{C}$ from the epilimnion during photosynthesis by phytoplankton and its sedimentation and later release in the hypolimnion by microbial decomposition results in $\delta^{13} \mathrm{C}$ values that are usually higher in the epilimnion than in the hypolimnion (Cohen, 2003). Lake dynamics, under the effects of external forcing factors (i.e. wind stress) ultimately controls upwelling of carbon isotope depleted waters to the surface. Therefore, biological productivity alone is not necessarily the main control on $\delta^{13} \mathrm{C}$ values of subsequent organic matter (Mybro and Shapley, 2006).

Lago Chungará water dynamics are mainly governed by two contrasting situations (Hernández et al., 2008): (1) background conditions, including periods of lake water stratification, represented by the dark-green laminae and (2) a water column subjected to episodes of very strong mixing, which are represented by the white laminae. During the stratified periods, concentrations of oxygen and other electron acceptors typically decrease in the hypolimnion, while $\mathrm{CO}_{2(\mathrm{aq})}, \mathrm{CH}_{4}$, and nutrients accumulate (Bedard and Knowles, 1991). These dissolved nutrients, as well as the accumulated $\mathrm{CO}_{2(\text { aq }}$ and $\mathrm{CH}_{4}$, are released into the entire lake during mixis (Houser et al., 2003), when the super-blooms that generate the white laminae occur. Under these circumstances, the light carbon enriched upwelled waters from the hypolimnion could hinder the effects of enhanced productivity on $\delta^{13} \mathrm{C}$, generating as a result $\delta^{13} \mathrm{C}$ depleted white laminae.

Hurrell (2010) suggest that $\% \mathrm{C}_{\text {diatom }}$ results can be used as indicators of sample cleanness. Samples with $>1 \%$ carbon may still contain carbon which is external to the diatom frustules. However, it is also possible that the amount of carbon in the frustules varies according to environmental conditions and species. For example, Crosta et al. (2002) found that when there are larger quantities of iron in the water, marine diatoms reduce their consumption of silica

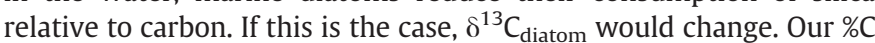
diatom data do not allow further environmental interpretations, but as all values presented here are $<1 \%$ they establish evidence that the $\delta^{13} \mathrm{C}_{\text {diatom }}$ reported data are suitable for palaeoenvironmental reconstructions.

\section{3. $\delta^{18} O_{\text {diatom }}$ inter-cycle relationships (white laminae formation)}

$\delta^{18} \mathrm{O}_{\text {diatom }}$ values through the inter-cycle relationships help to understand the underlying processes involved in the formation of the white laminae. The super-blooms that produce the white laminae have to be triggered by an exceptional injection of nutrients into the water column which may or may not be associated with a water volume change. The start of the rhythmite is usually accompanied by $\delta^{18} \mathrm{O}_{\text {diatom }}$ enrichment (Table $2 \mathrm{~A}$ ), indicating a decrease in the $\mathrm{P} / \mathrm{E}$ ratio, which would probably be accompanied by a drop in the lake water level and a remobilization of nutrients from the hypolimnion (Fig. 6A and $\mathrm{B}$, transition 1 ).

Episodes of diatom super-blooms occur throughout the whole studied section, but their formation is a time scale-dependent process. At decadal-centennial scales, white laminae are brighter (higher values in the grey colour curve) and thicker (around $6 \mathrm{~mm}$ ) with higher isotope oxygen values (up to $+39.2 \%$ ) than during other laminae deposition periods (Hernández et al., 2010). Deposition of these white laminae is related to low-stand conditions, as shown in the uppermost part of the three shallowing upward trends observed in the $\delta^{18} \mathrm{O}_{\text {diatom }}$ record (Fig. 5). However, at interannual scales, the inter-cycle isotope relationships reveal that changes to both drier or wetter conditions may trigger the formation of the white laminae, but that falls in lake level were more likely responsible for the development of the super-blooms (Table 2A).

\section{4. $\delta^{18} \mathrm{O}_{\text {diatom }}$ and $\delta^{13} C_{\text {diatom }}$ intra-cycle relationships (green laminae formation)}

The relationship between $\delta^{18} \mathrm{O}_{\text {diatom }}$ and $\delta^{13} \mathrm{C}_{\text {diatom }}$ provides a means of better understanding the environmental processes involved in the origin of the green laminae. $\delta^{13} C_{\text {diatom }}$ enrichments in all the studied intra-cycle relationships (Table 1 ) suggest no or reduced mixing of the water column. However, according to the $\delta^{18} \mathrm{O}_{\text {diatom }}$ data, these more stable water conditions can occur under two contrasting P/ $\mathrm{E}$ regimes. The most common intra-cycle relationships which show $\delta^{18} \mathrm{O}_{\text {diatom }}$ depletions $(65 \% ; \mathrm{n}=23$ ) (Table $2 \mathrm{~B}$ ), indicate that the lake tended to progressively recover to the previous environmental state by means of a gradual increase in water availability (Fig. 6A and C, transition 2 and 3). Conversely, the relationships which show $\delta^{18} \mathrm{O}$ diatom enrichments indicate the recovery to a lower lake level after a super-bloom caused by a large allochthonous nutrient input associated with enhanced rainfall. This is manifested by the prevalence of $\delta^{18} \mathrm{O}_{\text {diatom }}$ depletions that precede those super-blooms $(90 \% ; n=10)$ (Table Suplementary Material). This model suggests that the green laminae occurred most of the time as a result of the recovery phase favoured by lake water rise. Finally, when the lake is already in the recovery phase (transitional and baseline conditions) it may evolve, indistinctly, towards higher or lower lake water levels, as indicated by the light- to dark-green isotope transitions (enrichments $=56 \%$; $\mathrm{n}=9$ ) (Fig. 6A and C, transition 4).

\subsection{Climate forcing of the laminae formation}

Rainfall and temperature oscillations over South America are due to a complex interplay of large scale ocean-atmosphere processes, such as El Niño Southern Oscillation, the Pacific Decadal Oscillation, the Southern Annual Mode or the Antarctic Oscillation (Moy et al., 2009). These largescale processes play a role on both temperature oscillations at several timescales and on the amount and distribution of precipitation through changes in the strength and latitudinal position of the wind belts. Among these large-scale ocean-atmosphere processes, the interannual climate variability over the Andean Altiplano is mainly related to changes of the SST at the Tropical Pacific (Garreaud et al., 2003). In addition, high altitude tropical regions are very sensitive to relatively small changes in radiative forcing. Thus, solar activity has also exerted a strong influence at different temporal scales, playing a key role at century-scale tropical climate variability during the Late Holocene modulating both precipitation and temperature (Gray et al., 2010; Polissar et al., 2006). 


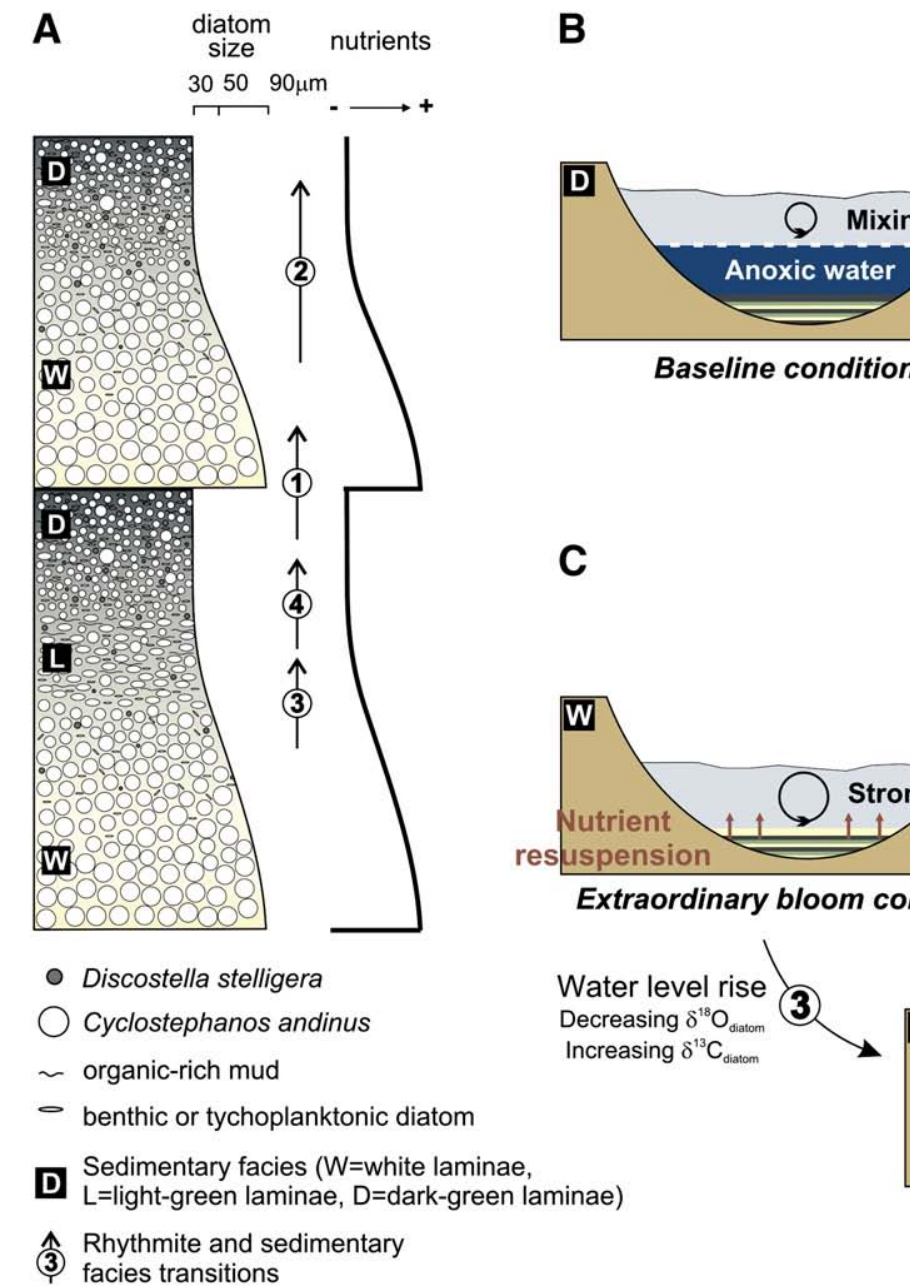

\section{Water level drop Increasing $\delta^{18} O_{\text {diatom }}$}

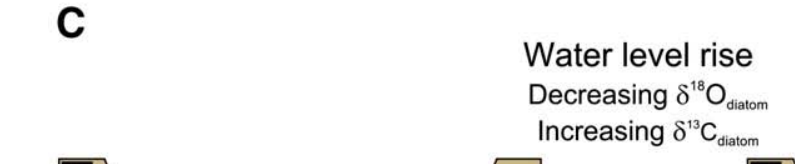

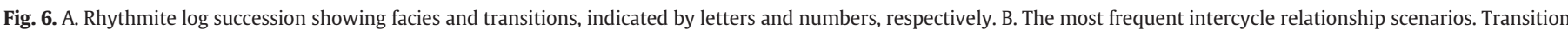

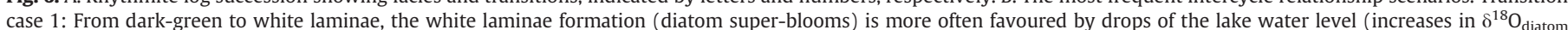

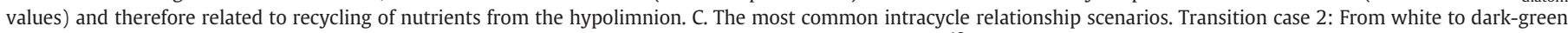

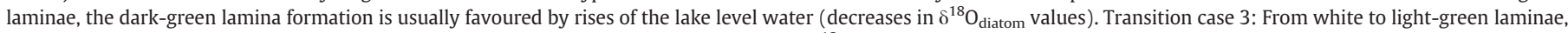

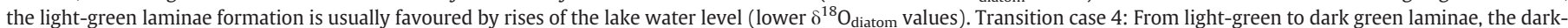
green laminae formation is almost indistinctly favoured by drops or rises of the lake water level, with a slight predominance of the former as the $\delta^{18} \mathrm{O}_{\mathrm{diatom}}$ show.

In the Andean Altiplano, ENSO involves drier or wetter regional climatic patterns during El Niño or La Niña phases, respectively (Valero-Garcés et al., 2003; Vuille and Werner, 2005). However, regionally, dry La Niña years and wet El Niño years are not completely uncommon, which indicates that the relationship between SSTs in the tropical Pacific and precipitation anomalies in the central Andes is not straightforward (Garreaud et al. 2003). For instance, analysis of observed data from the '11-year Schwabe cycles' shows a reduction of precipitation around the Equator corresponding to anomalously cold SSTs analogous to the pattern that occurs during La Niña years, with lagged El Niño-like conditions a couple of years later (Gray et al., 2010; Meehl et al., 2008, 2009). However, there is a significant relationship between Andean Altiplano precipitation and the zonal winds modulated by decadal and multidecadal variations in solar activity (Theissen et al., 2008). The sign and strength of these zonal winds (easterly/westerly) are also responsible for the climate conditions (wet/dry) in the Andean Altiplano.

Theissen et al. (2008) proposed that enhanced westerly flow from the tropical Pacific, which would reduce the delivery of moisture from the east, modulated by decadal and multidecadal variations in solar activity is the most likely cause of the long-term mid-Holocene aridity over the Andean Altiplano. Increases in the solar activity would play a positive feedback in the enhancing the westerly flow. This hypothesis supports the $\delta^{18} \mathrm{O}_{\text {diatom }}$ data from the Lago Chungará rhythmites showing that the solar activity and its interaction with the ENSO phenomena were the main processes that ruled the climatic variability of the Andean Altiplano region at decadal time scale during the Late Glacial-Early Holocene transition (Hernández et al., 2010).

The influence of solar activity and ENSO variability on the Lago Chungará sediments was previously identified by means of a TimeFrequency (TF) analysis (Hernández et al., 2010) (white colour bands in Fig. 7). As discussed above, rhythmite formation is caused by diatom super-blooms which in turn are controlled by the degree of mixing and the lake level oscillations. These factors are directly related to the wind intensity and precipitation, which would primarily be induced by the complex climate dynamics. The TF analysis performed in Hernández et al. (2010) shows that white laminae formation would be mainly influenced by the 11-year Schwabe cycles (Fig. 7). This decadal solar activity is responsible for the enhancement of the westerlies over the Altpilano, reducing the delivery of moisture from the east. This has already been described as the main process responsible for the laminae formation in Lago Titicaca during the midHolocene (Theissen et al., 2008). The interannual and decadal ENSO frequencies might have also played a role in the laminae formation. The periods with more intense (higher intensity grey-colour curve values) and better developed (thicker) white laminae at 11,900, 11,750 , and 11,550 cal years BP correspond to periods when both greater solar activity and ENSO (El Niño-like dry phase) phenomena 

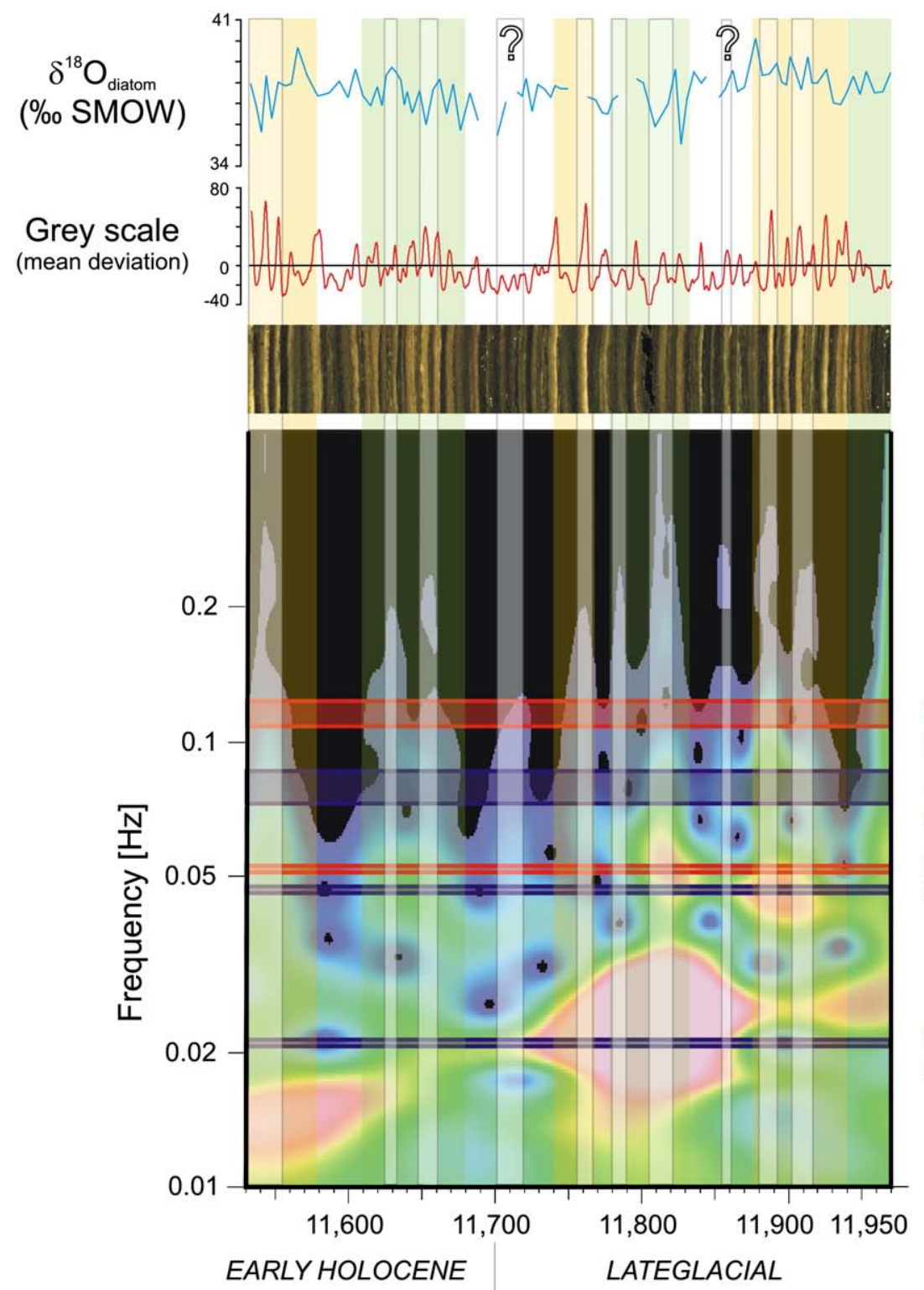

Time [cal. years BP]
$7.16-8.9$ years

(Strong ENSO: 7 - 9 years)

$11.13-12.97$ years

(Schwabe cycles: 11 years)

18.62 years (Strong ENSO: 15 - 17 years)

22.27 years (Hale cycles: 23 years)

39.37 years

(Brückner cycles: 35 years)

\section{Energy $\quad 0.5$}

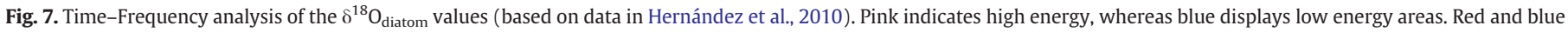

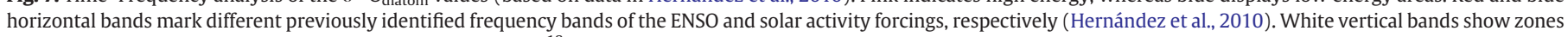

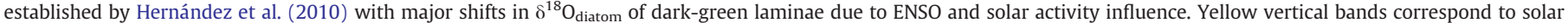

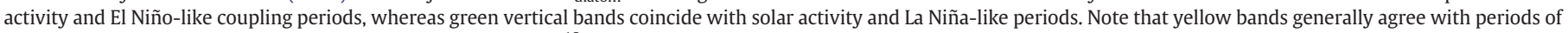

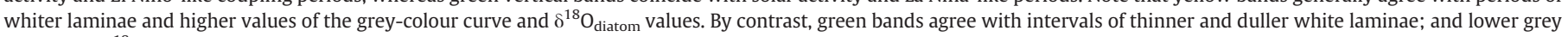
colour and $\delta^{18} \mathrm{O}_{\text {diatom }}$ values.

were recorded (yellow colour bands of Fig. 7). This relationship however is not straightforward, since there are intervals where white laminae are thinner and darker that correspond to higher solar activity and ENSO moments at 11,950, 11,800 and 11,650 cal years BP. These latter periods are however dominated by La Niña-like phases of the ENSO which represents more humid conditions over the Andean Altiplano (green colour bands in Fig. 7). This working hypothesis is supported by the $\delta^{18} \mathrm{O}_{\text {diatom }}$ record which shows lighter isotope values for these periods (Fig. 7). Finally, those periods with the thinnest and less bright white laminae (11,850, 11,700 and 11,600 cal years BP) correspond to a sharp decrease of solar activity and ENSO phenomena.
This decrease in activity of both phenomena, and the climate changes that resulted at Lago Chungará, probably restricted the development of the diatom super-blooms. Hence, the positive feedback of the solar activity and ENSO phenomena on the local climate could be mainly responsible for the diatom super-blooms and accumulation of the white laminae.

\section{Conclusions}

The Late Glacial to Early Holocene (11,990 and 11,530 cal years BP) rhythmites from Lago Chungará record multiannual diatom super- 
blooms lasting from days to weeks (white laminae) and the lake hydrology recovery towards the baseline conditions throughout several years of sedimentation (dark-green laminae). Self-sedimentation phenomena taking place immediately after the diatom super-blooms cannot be discarded as a sign of the end of the super-bloom (light-green laminae). The diatom super-blooms mainly occurred during episodes of extreme turbulent conditions affecting the whole water column, this caused the upwelling of nutrient-rich hypolimnion waters and/or by injection on nutrients by increased runoff.

$\delta^{18} \mathrm{O}_{\text {diatom }}$ in Chungará lacustrine record can be used as an indicator of change in the P/E related to Late Glacial-Early Holocene climate variation. $\delta^{18} \mathrm{O}_{\text {diatom }}$ indicates that the white laminae formation was usually favoured by changes from wet-to-dry conditions, whereas the green laminae formation was especially prompted by lake level rise. Furthermore, the isotope data also show that at decadal-centennial scales the depositional units which contain better developed (whiter and thicker) white laminae are related to low-stand conditions.

$\delta^{13} C_{\text {diatom }}$ variability is more complex and requires further study. Variability is classically interpreted as a function of changes in biological productivity, with higher productivity periods responsible for higher $\delta^{13} \mathrm{C}$. However at multiannual scales other in-lake process may be more predominant especially influences of changes in $\mathrm{CO}_{2(\mathrm{aq})}$ concentration due to changes in the water mixing regimes.

The diatom super-blooms were induced by the complex interplay of solar activity and ENSO variability. The intervals with better developed white laminae correspond to periods of greater solar activity and El Niño-like dry phases, whereas thinner and darker white laminae correspond to La Niña-like conditions. Thus, the positive feedback of the solar activity and ENSO phenomena seems to be the main responsible for the diatom super-blooms and accumulation of the white laminae.

High resolution isotope analysis of the oxygen and carbon isotopes in diatom silica in this uniquely laminated sequence has displayed links between limnology, runoff, hydrology and climate forcing at different time scales. Solar activity and ENSO phenomena have triggered nutrient and carbon release from the hypolimnion and sediments that led to diatom super-blooms. Such phenomena may be found in many lakes, but few preserve evidence in their sedimentary processes and architecture. Further work on other parts of this lacustrine record and in similarly laminated sites may reveal the full impact of these multiannual events on lake ecosystems and biogeochemical cycles.

Supplementary materials related to this article can be found online at doi:10.1016/j.palaeo.2010.11.020.

\section{Acknowledgments}

The Spanish Ministry of Science and Innovation funded the research at Lago Chungará through the projects ANDESTER (BTE2001-3225), Complementary Action (BTE2001-5257-E), LAVOLTER (CGL200400683/BTE), GEOBILA (CGL2007-60932/BTE) and CONSOLIDER-Ingenio 2010 GRACCIE (CSD2007-00067). A. Hernández have benefited from a FPI grant from The Spanish Ministry of Science and Innovation. The Limological Research Center (USA) provided the technology and expertise to retrieve the cores. We are grateful to CONAF (Chile) for the facilities provided in Parque Nacional Lauca. The NIGL (UK) funded the isotope analyses. Chris P. Kendrick is thanked for conducting the carbon isotope measurements. We also wish to thank Juan J. Pueyo for valuable discussions on the manuscript and Alice Chang for her insight on the implications of self-sedimentation processes in the formation of the laminated sediments.

\section{References}

Alldredge, A.L., Gotschalk, C., Passow, U., Riebesell, U., 1995. Mass aggregation of diatom blooms: insights from a mesocosm study. Deep Sea Research. Part II: Topical Studies in Oceanography 42, 9-27.
Barker, P.A., Street-Perrott, F.A., Leng, M.J., Greenwood, P.B., Swain, D.L., Perrott, R.A Telford, R.J., Ficken, K.J., 2001. A 14 ka oxygen isotope record from diatom silica in two alpine tarns on Mt Kenya. Science 292, 2307-2310.

Barker, P.A., Leng, M.J., Gasse, F., Huang, Y., 2007. Century-to-millennial scale climatic variability in Lake Malawi revealed by isotope records. Earth and Planetary Science Letters 261, 93-103. doi:10.1016/j.epsl.2007.06.010.

Bedard, C., Knowles, R., 1991. Hypolimnetic $\mathrm{O}_{2}$ consumption, denitrification, and methanogenesis in a thermally stratified lake. Canadian Journal of Fisheries and Aquatic Sciences 48, 1048-1054.

Bird, B.W., Abbott, M.B., Kutchko, B., Finney, B.P., 2009. A 2000-year varve-based climate record from the Central Brooks Range, Alaska. Journal of Paleolimnology 41, 25-41.

Bradbury, P., Cumming, B., Laird, K., 2002. A 1500-year record of climatic and environmental change in Elk Lake, Minnesota III: measures of past primary productivity. Journal of Paleolimnology 27, 321-340.

Chang, A.S., Patterson, R.T., McNeely, R., 2003. Seasonal sediment and diatom record from late Holocene laminated sediments, Effingham Inlet, British Columbia, Canada. Palaios 18, 477-494.

Christoforou, P., Hameed, S., 1997. Solar cycle and the Pacific 'centers of action' Geophysical Research Letters 24, 293-296.

Cohen, A.S., 2003. Paleolimnology: the History and Evolution of Lake Systems. Oxford University Press, New York.

Crosta, X., Shemesh, A., 2002. Reconciling down core anticorrelation of diatom carbon and nitrogen isotopic ratios from the Southern Ocean. Paleoceanography 17. doi:10 1029/ 2000PA000565.

Crosta, X., Shemesh, A., Salvignac, M.E., Gildor, H., Yam, R., 2002. Late quaternary variations of elemental ratios $(\mathrm{C} / \mathrm{Si}$ and $\mathrm{N} / \mathrm{Si})$ in diatom-bound organic matter from the Southern Ocean. Deep Sea Research. Part II: Topical Studies in Oceanography 49, 1939-1952.

Des Combes, H.J., Esper, O., De la Rocha, C.L., Abelmann, A., Gersonde, R., Yam, R., Shemesh, A., 2008. Diatom $\delta^{13} \mathrm{C}, \delta^{15} \mathrm{~N}$, and $\mathrm{C} / \mathrm{N}$ since the Last Glacial Maximum in the Southern Ocean: potential impact of species composition. Paleoceanography 23. doi:10.1029/2008PA0001589.

Dorador, C., Pardo, R., Vila, I., 2003. Variaciones temporales de parámetros físicos, químicos y biológicos de un lago de altura: el caso del Lago Chungará. Revista Chilena de Historia Natural 76, 15-22.

Garreaud, R.D., Vuille, M., Clement, A.C., 2003. The climate of the Altiplano: observed current conditions and mechanisms of past changes. Palaeogeography, Palaeoclimatology, Palaeoecology 194, 5-22.

Gasse, F., Fontes, J.C., 1992. Climatic Changes in Northwest Africa during the Last Deglaciation (16-7 ka BP). NATO ASI Series, 12. Kluwer Academia Publishers, Dordrecht, pp. 295-325.

Geyh, M., Grosjean, M., 2000. Establishing a reliable chronology of lake level changes in the Chilean Altiplano: a result of close collaboration between geochronologists and geomorphologists. Zbl Geol Paläont Teil 1, 985-995.

Geyh, M., Schotterer, U., Grosjean, M., 1998. Temporal changes of the ${ }^{14} \mathrm{C}$ reservoir effect in lakes. Radiocarbon 40, 921-931.

Giralt, S., Moreno, A., Bao, R., Sáez, A., Prego, R., Valero, B.L., Pueyo, J.J., GonzálezSampériz, P., Taberner, C., 2008. Statistical approach to distangle environmental forcings in a lacustrine record: the Lago Chungará case (Chilean Altiplano). Journal of Paleolimnology 40, 195-215. doi:10.1007/s10933-007-9151-9.

Gray, L.J., Beer, J., Geller, M., Haigh, J.D., Lockwood, M., Matthes, K., Cubasch, U., Fleitmann, D., Harrison, G., Hood, L., Luterbacher, J., Meehl, G.A., Shindell, D., van Geel, B., White, W., 2010. Solar influence on climate. Reviews of Geophysics 48, RG4001. doi:10.1029/2009RG000282.

Grimm, K.A., Lange, C.B., Gill, A.S., 1996. Biological forcing of hemipelagic sedimentary laminae: evidence from ODP site 893, Santa Barbara Basin, California. Journal of Sedimentary Research 66, 613-624.

Grimm, K.A., Lange, C.B., Gill, A.S., 1997. Self-sedimentation of phytoplankton blooms in the geologic record. Sedimentary Geology 110, 151-161.

Harris, G.P., 1986. Phytoplankton Ecology. Structure, Function and Fluctuation. Chapman \& Hall, Londres, p. 384.

Hernández, A., Bao, R., Giralt, S., Leng, M.J., Barker, P.A., Sáez, A., Pueyo, J.J., Moreno, A. Valero-Garcés, B.L., Sloane, H.J., 2008. The palaeohydrological evolution of Lago Chungará (Andean Altiplano, northern Chile) during the Lateglacial and early Holocene using oxygen isotopes in diatom silica. Journal of Quaternary Science 23 351-363. doi:10.1002/jqs.1173.

Hernández, A., Giralt, S., Bao, R., Saéz, A., Leng, M.J., Barker, P.A., 2010. ENSO and solar activity signals from oxygen isotopes in diatom silica during late glacial - Holocene transition in Central Andes $\left(18^{\circ} \mathrm{S}\right)$. Journal of Paleolimnology 44, 413-429. doi:10.1007/s10933-010-9412-x.

Herrera, C., Pueyo, J.J., Sáez, A., Valero-Garcés, B.L., 2006. Relación de aguas superficiales y subterráneas en el área del lago Chungará y lagunas de Cotacotani, norte de Chile: un estudio isotópico. Revista Geologica de Chile 33, 299-325.

Herzschuh, U., Mischke, S., Meyer, H., Plessen, B., Zhang, C., 2010. Lake nutrient variability inferred from elemental $(\mathrm{C}, \mathrm{N}, \mathrm{S})$ and isotopic $\left(\delta^{13} \mathrm{C}, \delta^{15} \mathrm{~N}\right)$ analyses of aquatic plant macrofossils. Quaternary Science Reviews 29, 2161-2172. doi:10.1016/j.quascirev.2010.05.011.

Houser, J.N., Bade, D.L., Cole, J.J., Pace, M.L., 2003. The dual influences of dissolved organic carbon on hypolimnetic metabolism: organic substrate and photosynthetic reduction. Biogeochemistry 64, 247-269.

Hurrell, E, 2010. Climate change and biogeochemical cycles on East African mountains revealed by stable isotopes of diatom frustules. PhD thesis, University of Lancaster.

Imboden, D.M., Wüest, A., 1995. Mixing mechanisms in lakes. In: Lerman, A., Imboden, D.M., Gat, J.R. (Eds.), Physics and Chemistry of Lakes. Springer-Verlag, Berlin, pp. 83-138. 
Koutavas, A., Lynch-Stieglitz, J., Marchitto, T., Sachs, J., 2002. El Niño-like pattern in ice age tropical Pacific sea surface temperature. Science 297, 226-230.

Kröger, N., Poulsen, N., 2008. Diatoms: from cell wall biogenesis to nanotechnology. Annual Review of Genetics 42, 83-107.

Lamb, A.L., Leng, M.J., Sloane, H.J., Telford, R.J., 2005. A comparison of $\delta^{18} \mathrm{O}$ data from calcite and diatom silica from early Holocene in a small crater lake in the tropics. Palaeogeography, Palaeoclimatology, Palaeoecology 223, 290-302.

Leng, M.J., Marshall, J.D., 2004. Palaeoclimate interpretation of stable isotope data from lake sediment archives. Quaternary Science Reviews 23, 811-831. doi:10.1016/j. quascirev.2003.06.012.

Leng, M.J., Barker, P.A., 2006. A review of the oxygen isotope composition of lacustrine diatom silica for palaeoclimate reconstruction. Earth Science Reviews 75, 5-27. doi:10.1016/j.earscirev.2005.10.001.

Leng, M.J., Lamb, A.L., Heaton, T.H.E., Marshall, J.D., Wolfe, B.B., Jones, M.D., Holmes, J.A., Arrowsmith, C., 2005. Isotopes in lake sediments. In: Leng, M.J. (Ed.), Isotopes in Palaeoenvironmental Research. Springer, Dordrecht, pp. 147-184.

Leng, M.J., Sloane, H.J., 2008. Combined oxygen and silicon isotope analysis of biogenic silica. Journal of Quaternary Science 23, 313-319.

Margalef, R., 1978. Life forms of phytoplankton as survival alternatives in an unstable environment. Oceanologica Acta 1, 493-509.

Meehl, G.A., Arblaster, J.M., Branstator, G., van Loon, H., 2008. A coupled air-sea response mechanism to solar forcing in the Pacific region. Journal of Climate 21, 2883-2897. doi:10.1175/2007JCLI1776.1.

Meehl, G.A., Arblaster, J.M., Matthes, K., Sassi, F., van Loon, H., 2009. Amplifying the Pacific Climate System Response to a Small 11-Year Solar Cycle Forcing. Science 325, 1114. doi:10.1126/science. 1172872.

Meyers, P.A., Teranes, J.L., 2001. Sediment organic matter. In: Last, W.M., Smol, J.P. (Eds.), Tracking Environmental Change using Lake Sediments. : Physical and Geochemical Methods., Volume 2. Kluwer Academic Publishers, Dordrecht, The Netherlands, pp. 239-270.

Moreno, A., Giralt, S., Valero-Garcés, B.L., Sáez, A., Bao, R., Prego, R., Pueyo, J.J., GonzálezSampériz, P., Taberner, C., 2007. A 13 kyr high-resolution record from the tropica Andes: the Chungará Lake sequence $\left(18{ }^{\circ} \mathrm{S}\right.$, northern Chilean Altiplano). Quaternary International 161, 4-21. doi:10.1016/j.quaint.2006.10.020.

Morley, D.W., Leng, M.J., Mackay, A.W., Sloane, H.J., Rioual, P., Battarbee, R.W., 2004 Cleaning of lake sediment samples for diatom oxygen isotope analysis. Journal of Paleolimnology 31, 391-401.

Moy, C.M., Moreno, P.I., Dunbar, R.B., Kaplan, M.R., Francois, J.P., Villalba, R., Haberzettl T., 2009. Climate change in Southern South America during the last two millennia. In: Vimeux, F., Sylvestre, F., Khodri, M. (Eds.), Past Climate Variability in South America and Surrounding Regions. Springer, Dordrecht, Netherlands, pp. 3-27.

Moy, C.M., Seltzer, G.O., Rodbell, D.T., Anderson, D.M., 2002. Variability of El Niño/ Southern Oscillation activity at millennial timescales during the Holocene epoch. Nature 420, 162-165

Mybro, A., Shapley, M.D., 2006. Seasonal water-column dynamics of dissolved inorganic carbon isotopic compositions $\left(\delta^{13} \mathrm{C}_{\mathrm{DIC}}\right)$ in small hardwater lakes in Minnesota and Montana. Geochimica et Cosmochimca Acta 70, 2699-2714.

Polissar, P.J., Abbott, M.B., Wolfe, A.P., Bezada, M., Rull, V., Bradley, R.S., 2006. Solar modulation of Little Ice Age climate in the tropical Andes. Proceedings National Academy of Sciences 103, 8937-8942.
Pueyo, J.J., Sáez, A Giralt, S., Valero-Garcés, B.L, Moreno, A., Bao, R., Schwalb, A Herrera, C., Klosowska, B., Taberner, C., Submitted. Carbonate sedimentation and large ${ }^{13} \mathrm{C}$ enrichments in moderately alkaline lacustrine records: the Lake Chungará. Palaeoclimatology, Palaeogeography, Palaeoecology.

Rasband, W.S., 1997-2009. ImageJ, U. S. National Institutes of Health, Bethesda, Maryland, USA. http://rsb.info.nih.gov/ij/.

Reynolds, C.S., 2006. The Ecology of Phytoplankton. Cambridge University Press, Cambridge, UK.

Rodbell, D.T., Seltzer, G.O., Anderson, D.M., Abbott, M.B., Enfield, D.B., Newman, J.H., 1999. An 15, 000-year record of El Niño-driven alluviation in southwestern Ecuador. Science 283, 516-520.

Round, F.E., Crawford, R.M., Mann, D.G., 1990. The Diatoms: Biology and Morphology of the Genera. Cambridge University Press, Cambridge.

Sáez, A., Valero-Garcés, B.L., Moreno, A., Bao, R., Pueyo, J.J., González-Sampériz, P., Giralt, S., Taberner, C. Herrera, C. Gibert, R.O. 2007. Volcanic controls on lacustrine sedimentation: the late Quaternary depositional evolution of Lake Chungará (Northern Chile). Sedimentology 54, 1191-1222. doi:10.1111/j.1365-3091.2007.00878.x.

Sandweiss, D.H., Maasch, K.A., Burger, R.L., Richardson III, J.B., Rollins, H.B., Clement, A., 2001. Variation in Holocene El Niño frequencies: climate records and cultural consequences in ancient Peru. Geology 29, 603-606.

Schneider-Mor, A., Yam, R., Bianchi, C., Kunz-Pirrung, M., Gersonde, R., Shemesh, A., 2005. Diatom stable isotopes, sea ice presence and sea surface temperature records of the past $640 \mathrm{ka}$ in the Atlantic sector of the Southern Ocean. Geophysical Research Letters 32, L10704.

Sicko-Goad, L., Stoermer, E.F., Kociolek, J.P., 1989. Diatom resting cell rejuvenation and formation: time course, species records and distribution. Journal of Plankton Research 11, 375-389.

Singer, A.J., Shemesh, A., 1995. Climatically linked carbon-isotope variation during the past 430, 000 years in Southern-Ocean sediments. Paleoceanography 10,171-177.

Smetacek, V.S., 1985. Role of sinking in diatom life-history cycles: ecological, evolutionary and geological significance. Marine Biology 84, 239-251.

Talbot, M.R., Allen, P.A., 1996. Lakes. In: Reading, H.G. (Ed.), Sedimentary Environments: Processes, Facies and Stratigraphy. Blackwell Science, Oxford, pp. 83-124.

Theissen, K.M., Dunbar, R.B., Rowe, H.D., Mucciarone, D.A., 2008. Multidecadal- to century-scale arid episodes on the Northern Altiplano during the middle Holocene. Palaeogeography, Palaeoclimatology, Palaeoecology 257, 361-376. doi:10.1016/j. palaeo.2007.09.011

Thornton, D.C.O., 2002. Diatom aggregation in the sea: mechanisms and ecological implications. European Journal of Phycology 37, 149-161.

Valero-Garcés, B.L., Delgado-Huertas, A., Navas, A., Edwards, L., Schwalb, A., Ratto, N., 2003. Patterns of regional hydrological variability in central-southern Altiplano $\left(18^{\circ}-26^{\circ} \mathrm{S}\right)$ lakes during the last 500 years. Palaeogeography, Palaeoclimatology, Palaeoecology 194, 319-338.

Vuille, M., Bradley, R., Werner, M., Keimig, F., 2003. 20th century climate change in the tropical Andes: observations and model results. Climatic Change 59 (75-99), 2003.

Vuille, M., Werner, M., 2005. Stable isotopes in precipitation recording South American summer monsoon and ENSO variability: observations and model results. Climate Dynamics 25, 401-413. doi:10.1007/s00382-005-0049-9.

Winder, M., Hunter, D., 2008. Temporal organization of phytoplankton communities linked to physical forcing. Oecologia 156, 179-192. 